\title{
Bioaccumulation of iron, selenium, nitrate, and proteins in chard shoots
}

\author{
E. Hernández-Castro ${ }^{1}$, L.I. Trejo-Téllez ${ }^{1 *}$, F.C. Gómez-Merino ${ }^{2}$, M.N. Rodríguez- \\ Mendoza $^{1}$, P. Sánchez-García ${ }^{1}$, A. Robledo-Paz ${ }^{1}$
}

${ }^{1}$ Colegio de Postgraduados, Campus Montecillo, C.P. 56230, Montecillo, Texcoco, State of Mexico. ${ }^{2}$ Colegio de Postgraduados, Campus Córdoba, , C.P. 94946, Amatlán de los Reyes, Veracruz, Mexico. *Corresponding author: tlibia@colpos.mx

\begin{abstract}
The present research was aimed at the foliar biofortification of chard plants with iron and selenium and at determining the influence of this treatment on the accumulation of these elements, as well as proteins and nitrate, in the aerial portion (shoot) of chard. A $3^{2}$ factorial experiment was conducted for the above purpose, and the study factors were the foliar applications of $\mathrm{Fe}\left(0,2500\right.$ and $\left.5000 \mathrm{mg} \mathrm{L}^{-1}\right)$ and $\mathrm{Se}\left(0,10\right.$ and $\left.20 \mathrm{mg} \mathrm{L}^{-1}\right)$. The foliar applications were performed every 15 days for a total of four spray applications. The variables evaluated were the accumulations of $\mathrm{Fe}$, Se, proteins, and nitrate in the shoot. Two samples were collected after performing the second and fourth foliar spray applications. The results indicate that increasing application concentrations of $\mathrm{Fe}$ and $\mathrm{Se}$ promote greater foliar accumulations of these elements. Foliar applications of Se did not affect the accumulation of nitrate; however, a greater foliar accumulation of Se produced a greater accumulation of proteins. On the other hand, after only four foliar spray applications of Fe at a dose of $5000 \mathrm{mg} \mathrm{L}^{-1}$, there was a statistically significant accumulation of nitrate, which had a positive correlation with the lower accumulation of proteins.
\end{abstract}

Keywords: Biofortification, Iron, selenium, protein, nitrate, nutrient accumulation

\section{Introduction}

The extent of micronutrient deficiency in human food has exhibited an increasing trend, which has garnered the attention of decision makers of food and nutritional security policy (FAO, 2011).

In terms of human health complications caused by a lack of micronutrients in the diet, iron $(\mathrm{Fe})$ deficiency is the most expansive problem in the world, affecting over two billion people, equivalent to almost one-third of the current total population of the planet. The most obvious impact of this deficiency is iron anemia, which contributes significantly to the death of mothers and infants in vulnerable populations with limited resources, while the "hidden" effects extend to different aspects of the growth and development of the individual (Thompson, 2007). 
Selenium is also an essential micronutrient for human health (Wu et al., 2015). A diet low in selenium (Se) is associated with health disorders such as oxidative stress, low fertility, and increased incidences of cancers. In addition, selenium is necessary for the proper functioning of the immune system because it imparts protection against viral infections and is a component of selenoproteins, which are crucial components of antioxidant defense mechanisms (Broadley et al., 2006). Indeed, Cartes et al. (2011) showed that selenite-pelleted ryegrass seeds (60 g Se ha-1) seem are a promissory tool to increase both the Se content and the antioxidant ability of plants.

The dominant forms of Fe and Se obtained through the diet affect the acceptabilities of these elements by the body. Iron is present in food in two forms: as heme Fe (derived from fresh foods such as meat, chicken or fish) and as a non-heme $\mathrm{Fe}$ (present in inorganic forms of plant foods such as cereals, legumes, grains, nuts, and vegetables). The heme form of Fe is easily absorbed by the body, and absorption rates of $25 \%$ are obtainable from the content of animal flesh under normal conditions, while $40 \%$ absorption is achievable when the body is deficient in this element. However, the absorption of non-heme Fe forms only ranges from $2-10 \%$ of the content of plant foods (Thompson, 2007), which is why it is important to achieve the greatest accumulation of $\mathrm{Fe}$ possible in plant tissues that will be consumed for the human or animal diet.

Organic forms of Se are more acceptable for human consumption than inorganic forms. For example, Semethionine, which comes from plant products, is directly used in protein metabolism, replacing essential methionine or used in selenium metabolism (Ježek et al., 2012). However, a negative side-effect of Se is that it increases the absorption of $\mathrm{NO}_{3}$ through methemoglobinemia the inhibition of the activity of the nitrate reductase (NR) enzyme. The toxicity of nitrate itself is relatively low; instead, its toxicity is determined by its conversion to nitrite. Nitrate can be converted into nitrite by bacterial reduction in both food (during processing and storage) and in the body itself (in the saliva and gastrointestinal tract). The nitrite in blood oxidizes iron from hemoglobin, producing, which is unable to carry oxygen and is very common in babies exposed to high concentrations of nitrate in foods. On the other hand, nitrate reacts with the amino acids of food in the stomach, producing nitrosamines and nitrosamides, which are substances that have been shown to have carcinogenic effects. This implies that when Se is supplied in organisms for human consumption, the nitrate levels in the generated foods should be measured.

To correct for micronutrient deficiencies, the FAO (2011) recommends that the best practice is the consumption of foods that contain micronutrients, which is why biofortification with these nutritional elements is a strategy that can be tested in fresh plants for consumption. Numerous studies have demonstrated the feasibility of increasing micronutrient concentrations in various crops by applying small amounts of fertilizers containing the desired element directly to the soil or leaves (Broadley et al., 2006). Recently, Rehman et al. (2014) reported that foliar application of boron $(0.32 \mathrm{M})$ improved yield-related traits and $\mathrm{B}$ grain contents with simultaneous decrease in panicle sterility.

In this regard, the agronomic biofortification of the edible portions of various food crops can be an effective way to increase the concentrations of micronutrients in these foods, while the effectiveness of this process depends on the species, the form of the fertilizer, and the application method (Mao et al., 2014).

In this context, this research focused on the foliar biofortification of Swiss chard, Beta vulgaris L. cv. Fordhook Giant plants with iron and selenium to determine the influence of this process on the accumulation of these elements, as well as proteins and nitrate, in foliar tissues. Biofortification with these elements was conducted both individually and in combination, evaluating the effect of foliar applications after both two and four foliar applications. 


\section{Materials and Methods}

The experiment was conducted under greenhouse conditions using chard plants as plant material (Beta vulgaris L. cv. Fordhook Giant Swiss Chard) that were installed in a hydroponic floating-room system. This hydroponic system had a piece of styrofoam that served as support to the plants and in which six holes were made where plastic cups with foam cubes were placed. Wooden crates lined with black plastic were installed to contain the nutrient solution, to which aquarium hoses were attached and connected to air pumps that were used to oxygenate the nutrient solution for 15 min every $3 \mathrm{~h}$, for a total of eight times a day. The floating hydroponic system was supplied with a complete Steiner nutrient solution, with a $\mathrm{pH}$ between 5.5 and 5.8. The addition of micronutrients to the nutrient solution was conducted using a commercial product with the following concentrations (in $\mathrm{mg} \mathrm{L}^{-1}$ ): $\mathrm{Fe}$, 5; Mn 2.33; Zn, 0.47; B, 0.43; Cu, 0.19; and Mo, 0.17 .

A $3^{2}$ factorial experiment was implemented, and the study factors were the foliar addition of $\mathrm{Fe}$ and $\mathrm{Se}$. The Fe levels sprayed on the foliage were 0,2500 , and $5000 \mathrm{mg} \mathrm{L}^{-1}$, while those of Se were 0,10 , and $20 \mathrm{mg} \mathrm{L}^{-1}$. The sources of Fe and $\mathrm{Se}$ were $\mathrm{FeSO}_{4} \cdot 7 \mathrm{H}_{2} \mathrm{O}$ and $\mathrm{Na}_{2} \mathrm{SeO}_{4}$, respectively. A total of four foliar applications were conducted at 15day intervals. The experimental unit was a container with six plants, with three replications per treatment. The experimental units were distributed completely at random in the greenhouse.

The aerial portion (shoot) and the root were harvested and weighed using a digital scale (OHAUS, model GT410D). Subsequently, the tissue was dried in an oven (CLIMATEST, model SW-17TA) for $72 \mathrm{~h}$ at $60^{\circ} \mathrm{C}$. After this period, the plant material was weighed using the digital scale already cited. The values for fresh and dry biomass were recorded in grams (g). Sampling was performed after two and four foliar spray applications and 15 days after the last application.
The concentrations of $\mathrm{Fe}$ and Se were determined after the wet digestion of the dry material with a mixture of nitric and perchloric acid (Alcántar and Sandoval, 1999). After digestion and filtering, the concentrations in the extracts were determined using inductively coupled plasma-optical emission spectrometry (ICP-OES, Varian 725-OES, Australia).

Proteins were extracted and quantified using Amido black for staining and bovine serum albumin as the standard for the calibration curve. The absorbance was determined using a spectrophotometer (Thermo Fisher Scientific, Genesys 10 UV, Madison, WI 53711, USA) at a wavelength of $640 \mathrm{~nm}$.

The concentration of nitrate was determined from 0.1 $\mathrm{g}$ of dry material, which was extracted as described by Alcántar and Sandoval (1999), and the concentration was determined with the use of a spectrophotometer as previously described.

The accumulations of $\mathrm{Se}, \mathrm{Fe}$, and nitrate were estimated from the dry biomasses and their concentrations, while the accumulation of proteins was determined from the concentration and the fresh biomass weight.

Analysis of variance (PROC ANOVA) was performed on the results and the means were compared using a Tukey test ( $\alpha \leq 0.05 \%)$, using the statistical program Statistical Analysis Software, version 9.3.

\section{Results and Discussion}

\subsection{Accumulation of Se in the shoot}

The accumulation of Se in the foliar tissue of chard was statistically affected by spraying Fe and Se after two foliar spray applications, whereas after four spray applications, it was only statistically affected by the Se factor and the interaction of Se with the Fe factor (Table 1).

The accumulation of Se in foliar tissue after two foliar spray applications (Figure 1A) was significantly higher for the Se foliar spray dose of $20 \mathrm{mg} \mathrm{L}^{-1}$ than for the 
rest of the treatments. However, after four foliar spray applications, the applications of Se (Figure 1B) were significantly greater than the control for both of the doses evaluated in the study ( 10 and $\left.20 \mathrm{mg} \mathrm{L}^{-1}\right)$, with the $20 \mathrm{mg}$ $\mathrm{L}^{-1}$ concentration causing the greatest accumulation of this element in the foliar tissue.
In higher plants, Se and S have a common metabolic route because of their physical and chemical similarities. Therefore, some species can absorb Se with $\mathrm{S}$ into their tissues when fertilized with this element (Kopsell et al., 2007).

Table 1. Statistical significance of study factors (Se and Fe) and their interaction on the variables evaluated after two and four foliar spray applications.

\begin{tabular}{|c|c|c|c|c|c|}
\hline \multirow{2}{*}{$\begin{array}{l}\text { Number of } \\
\text { Aspersions }\end{array}$} & \multirow{2}{*}{$\begin{array}{l}\text { Study } \\
\text { Factor }\end{array}$} & \multicolumn{4}{|c|}{ Accumulation } \\
\hline & & $\mathrm{Se}$ & $\mathrm{Fe}$ & Nitrate & Proteins \\
\hline \multirow{3}{*}{$\begin{array}{c}\text { Two } \\
\text { Aspersions }\end{array}$} & $\mathrm{Se}$ & $0.0236^{*}$ & $0.1886 \mathrm{~ns}$ & $0.2125 \mathrm{~ns}$ & $0.0010^{*}$ \\
\hline & $\mathrm{Fe}$ & $0.0213^{*}$ & $0.0007^{*}$ & $0.6033 \mathrm{~ns}$ & $0.0317^{*}$ \\
\hline & $\mathrm{Se} \times \mathrm{Fe}$ & $0.1174 \mathrm{~ns}$ & $0.0045^{*}$ & $0.7710 \mathrm{~ns}$ & $0.0009^{*}$ \\
\hline \multirow{3}{*}{$\begin{array}{c}\text { Four } \\
\text { Aspersions }\end{array}$} & $\mathrm{Se}$ & $<0.0001^{*}$ & $0.3598 \mathrm{~ns}$ & $0.9349 \mathrm{~ns}$ & $0.0272 *$ \\
\hline & $\mathrm{Fe}$ & $0.1678 \mathrm{~ns}$ & $<0.0001^{*}$ & $0.0022 *$ & $0.0002^{*}$ \\
\hline & $\mathrm{Se} \times \mathrm{Fe}$ & $<0.0001 *$ & $0.0004 *$ & $0.0141 *$ & $<0.0001 *$ \\
\hline
\end{tabular}

$\mathrm{ns}=$ not significant (Tukey’s test, 0.05$) ; *$ significant (Tukey's test, 0.05$)$

Increases in the concentration of sodium selenate in a nutrient solution can significantly increase the accumulation of Se in rapeseed leaves (Lefsrud et al., 2006). Similarly, the concentration of Se in the foliar tissue of watercress plants (Nasturtium officinale R. $\mathrm{Br}$.) has been observed to increase linearly with an increase in the concentration sodium selenate in the nutrient solution (from 0, 0.125, 0.25, 0.5, 1.0, 2.0 and $4.0 \mathrm{mg} \mathrm{L}^{-1}$ of Se) (Manion et al., 2013).

For winter wheat (Triticum aestivum L.), Ducsay and Lozek (2006) have reported that after foliar applications of $0.0,0.5,1.0,10$, and $20 \mathrm{~g} \mathrm{Se} \mathrm{ha}^{-1}$, the foliar applications of Se at 1, 10 and $20 \mathrm{~g} \mathrm{ha}^{-1}$ significantly increased the selenium content in grain to $0.061,0.088$, and $0.145 \mathrm{mg} \mathrm{kg}^{-1}$, respectively. Additionally, in basil (Ocimum basilicum L.) and cilantro (Coriandrum sativum L.) treated with three foliar applications of $\mathrm{Se}$ as selenate and selenite at intervals of five days and at concentrations of $0,2,4$, 8,16 , and $32 \mathrm{mg} \mathrm{L}^{-1}$, the accumulation of Se increased linearly for both sources of Se. The maximum concentrations of Se in the leaf tissue of basil and 
cilantro were 0.013 and $0.055 \mathrm{mg} \mathrm{g}^{-1}$ of dry weight, respectively (Kopsell et al., 2009).

There is evidence that the supplemental intake of Se from 0.1 to $0.2 \mathrm{mg} \mathrm{day}^{-1}$ helps to prevent various diseases, such as a number of types of cancer. For example, it is reported that the daily intake of 0.2 $\mathrm{mg}$ of Se reduces the incidence of lung and prostate cancers. Se also prevents cardiac disorders, viral infections, and thyroid deficiencies (Duffield et al., 2002).

A)

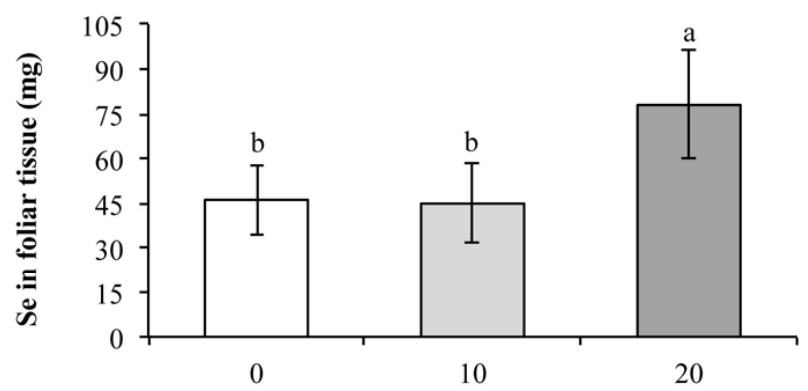

Se in foliar solution $\left(\mathrm{mg} \mathrm{L}^{-1}\right)$

B)

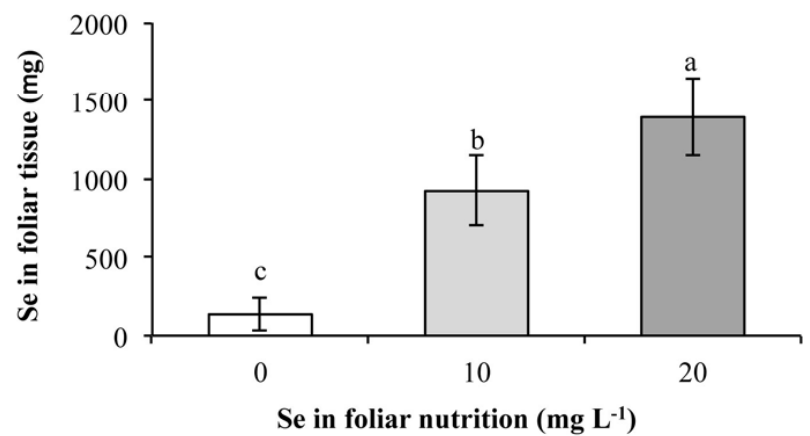

Figure 1. Principal effect of Se on the accumulation of Se in the aerial portion of chard plants after both two (A) and four (B) foliar spray applications delivered at intervals of $15 \mathrm{~d}$. Means \pm SD with different letters in each subfigure indicate significant differences (Tukey, 0.05).

In this research, after two foliar spray applications, the accumulations of Se in plant tissue were 44.9 and $77.9 \mu \mathrm{g}$ per shoot, respectively, for the spray applications of 10 and $20 \mathrm{mg} \mathrm{L}^{-1}$ of Se. After four foliar spray applications, Se accumulations of 920 and
$1393 \mu \mathrm{g}$ of Se per shoot were observed for the spray applications of 10 and $20 \mathrm{mg} \mathrm{L}^{-1}$ of Se, respectively. If the approximate biomass per plant after four foliar spray applications is considered to be $300 \mathrm{~g}$ and the recommended intake per serving is $100 \mathrm{~g}$, using the 
results obtained in this research, a person would be consuming between 306 and $464 \mu \mathrm{g}$ of Se from plants treated with 10 and $20 \mathrm{mg} \mathrm{L}^{-1}$ of $\mathrm{Se}$, respectively. There is a wide classification range of Se intake in humans, including toxic (approximately 500 $\mu \mathrm{g} \mathrm{day}^{-1}$ ), high (from 200 to $724 \mu \mathrm{g} \mathrm{day}^{-1}$ ), highly adequate (between 100 and $200 \mu$ day $^{-1}$ ), marginally adequate (from 30 to $90 \mu \mathrm{g} \mathrm{day}^{-1}$ ), and low or deficient (from 7 to $30 \mu$ day $^{-1}$ ) (Rayman, 2008).

The World Health Organization, the World Food and Agriculture Organization, and the International Atomic Energy Agency recommend an intake of 40 and $30 \mu$ day $^{-1}$ of Se for men and women, respectively. It has also been reported that a daily intake of $400 \mu \mathrm{g}$ of Se can have harmful effects on health (DRI, 2000).
However, Rayman (2004) reports that there is no evidence of toxicity, even at an intake level of $800 \mu \mathrm{g}$ day $^{-1}$ of Se during the course of several years.

On the other hand, prolonged exposure to high doses of Se (greater than $900 \mu$ gay $^{-1}$ ) may cause selenosis, the main symptoms of which are hair loss, nail fragility, a high prevalence for cavities, and neurological problems (Broadley et al., 2006).

There were no significant differences regarding the effect of the Fe x Se interaction after two foliar spray applications. However, after four spray applications (Figure 2), an increase in the application dose of Se caused an increase in the accumulation of Se in leaf tissue, regardless of the concentration of $\mathrm{Fe}$ in the foliar fertilizer.

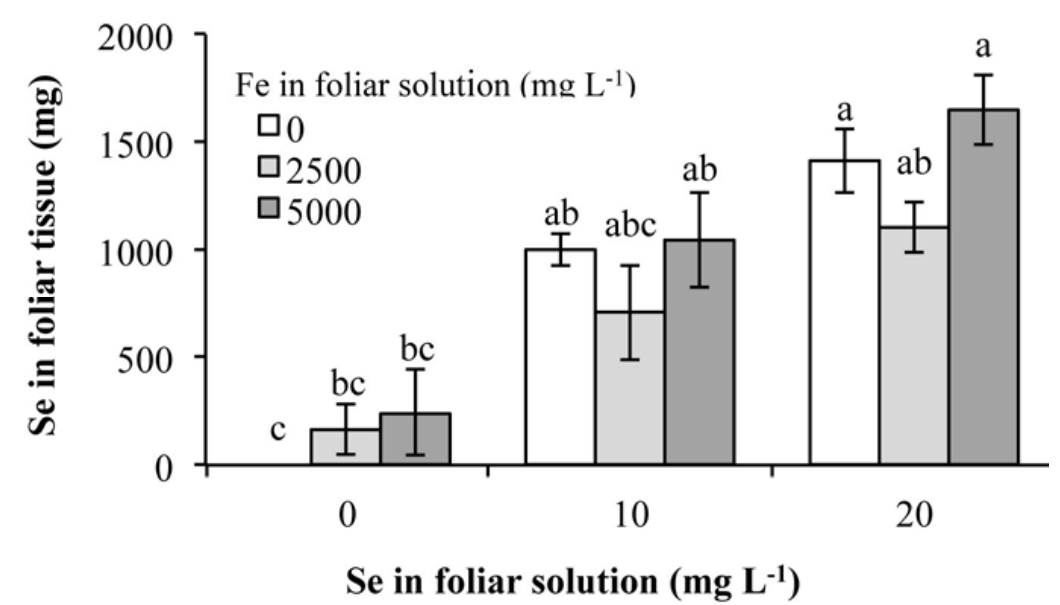

Figure 2. Effect of the Fe $x$ Se interaction on the accumulation of Se in the aerial portion of chard plants treated with four foliar spray applications at intervals of $15 \mathrm{~d}$. Means \pm SD with different letters indicate significant differences (Tukey, 0.05). 


\subsection{Accumulation of Fe in the shoot}

Significant principal effects of $\mathrm{Fe}$ and of the $\mathrm{Se} \times \mathrm{Fe}$ interaction on the accumulation of $\mathrm{Fe}$ in the aerial portion of the chard plants were observed for both sampling dates (Table 1).

In this study, there was marked difference in the accumulation of $\mathrm{Fe}$ in leaf tissue after two foliar spray applications (Figure 3A), as well as a positive relationship between the foliar dose of $\mathrm{Fe}$ and the accumulation of $\mathrm{Fe}$ in the plant tissue. After two foliar spray applications of $\mathrm{Fe}$ at a dose of 0,2500 , or 5000 $\mathrm{mg} \mathrm{L}^{-1}$, the foliar accumulations of Fe were 0.5 , 4.2, and $5.5 \mathrm{mg}$ per shoot, respectively, which implies accumulations that are $840 \%$ and $1100 \%$ greater than the control for the 2500 and $5000 \mathrm{mg} \mathrm{L}^{-1}$ of Fe treatments, respectively.

A)

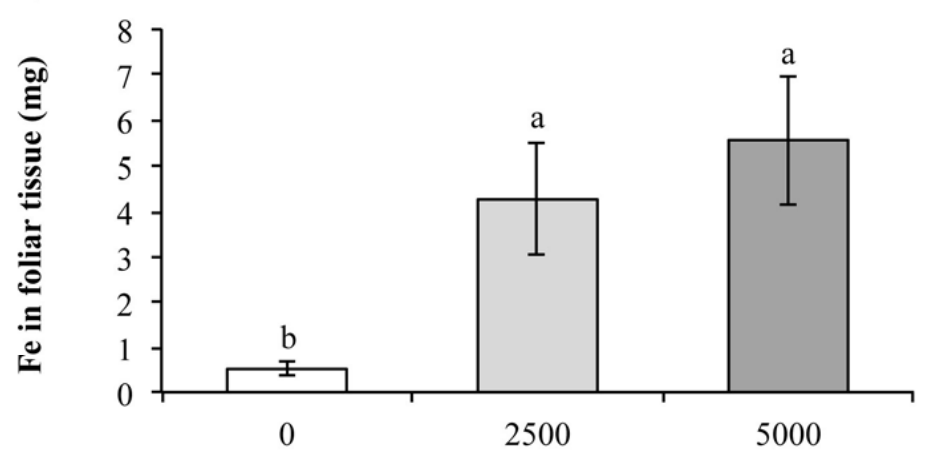

Fe in foliar solution $\left(\mathrm{mg} \mathrm{L}^{-1}\right)$

B)

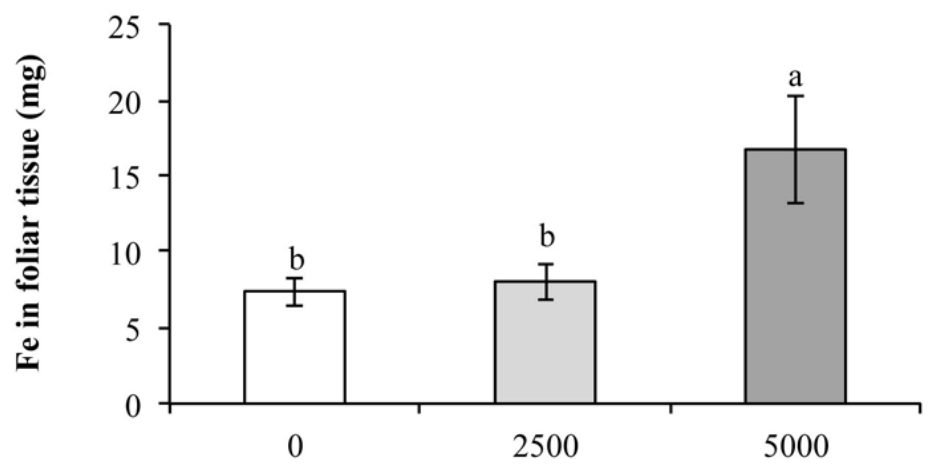

$\mathrm{Fe}$ in foliar solution $\left(\mathrm{mg} \mathrm{L}^{-1}\right)$

Figure 3. Principal effect of $\mathrm{Fe}$ on the accumulation of $\mathrm{Fe}$ in the aerial portion of chard plants after two (A) and four (B) foliar spray applications delivered at intervals of $15 \mathrm{~d}$. Means \pm SD with different letters in each subfigure indicate significant differences (Tukey, 0.05). 
Foliar applications of $\mathrm{FeSO}_{4}$ have been reported to impart a $16.97 \%$ increase in the Fe concentration of rice grain, which was evaluated as an alternative to combat $\mathrm{Fe}$ deficiencies in countries where rice is extensively consumed (Wei et al., 2012).

In this study, after four foliar applications of $\mathrm{Fe}$, a statistically significant increase in the accumulation of $\mathrm{Fe}$ in foliar tissue was only observed for the 5000 $\mathrm{mg} \mathrm{L}^{-1}$ application dose (Figure 3B), registering a $\mathrm{Fe}$ content that was $226 \%$ greater than that obtained for the shoots of the control treatment plants.

If we consider an intake of $100 \mathrm{~g}$ per serving and an approximate biomass of $300 \mathrm{~g}$ per plant, after the four foliar spray applications that coincide with the point of commercial crop harvest, potentially $2.46,2.67$, and $5.56 \mathrm{mg}$ of Fe would be consumed per serving of plant that was foliarly treated with $\mathrm{Fe}$ at concentrations of 0,2500 , and $5000 \mathrm{mg} \mathrm{L}^{-1}$, respectively. According to DRI (2000), the recommended daily intakes of Fe by age group are $11 \mathrm{mg}$ for children less than 1 year; from 7 to $10 \mathrm{mg}$ for children 1 to 8 years; between 8 and $11 \mathrm{mg}$ for men over 8 years; $8 \mathrm{mg}$ for women between 9 and 13 years and postmenopausal women; from 15 to $18 \mathrm{mg}$ for women of reproductive age; and $27 \mathrm{mg}$ for pregnant women.

After two foliar spray applications of increasing doses of $\mathrm{FeSO}_{4}$, the effect of the $\mathrm{Se} \times \mathrm{Fe}$ interaction causes an increased accumulation of $\mathrm{Fe}$ in the shoot. Although the differences are not significant, at increasing doses of $\mathrm{Se}$, the shoot concentration of $\mathrm{Fe}$ tends to decrease (Figure 4A). On the other hand, after four foliar spray applications of Fe at the $5000 \mathrm{mg} \mathrm{L}^{-1}$ dose, a greater leaf accumulation of this element was produced independent of the concentration of the Se application (Figure 4B).

There are similar reports of antagonistic effects of Se on the absorption of Fe for other species. For example, the application of $\mathrm{SeO}_{4}^{-2}$ on Brassica oleracea plants reduced the $\mathrm{Fe}$ concentration in foliar tissue when the concentration of Se was greater than 0 to $3.8 \mathrm{mg} \mathrm{L}^{-1}$ in the nutrient solution; on the other hand, the presence of $\mathrm{SeO}_{4}^{-2}$ increased the concentration of $\mathrm{K}$ in the leaf (Kopsell et al., 2000).

\subsection{Accumulation of nitrate in the shoot}

In the present study, the applications of Se did not result in any significant nitrate accumulation in aerial portions. On the other hand, spraying with $\mathrm{Fe}$, as well as the interaction $\mathrm{Se}^{\mathrm{x}} \mathrm{Fe}$, had significant effects on the accumulation of nitrate after only four applications (Table 1).

The maximum dose of nitrate permitted for human consumption has changed over time. The World Health Organization stipulates a maximum admissible daily nitrate intake of $5 \mathrm{mg} \mathrm{kg}^{-1}$ and $0.2 \mathrm{mg} \mathrm{kg}^{-1}$ of body weight for nitrite. However, an acceptable mean daily intake for the nitrate ion is also $3.7 \mathrm{mg} \mathrm{kg}^{-1}$ of body weight (Hord et al., 2011).

The amount of nitrate that accumulates in plant material is related to numerous factors, including the production system, the light intensity during the cultivation period, the activity of the nitrate reductase (NR) enzyme, and the concentrations of various cofactors of enzymes linked to processes of reduction of the nitrogen fractions (Campbell, 2001).

Multiple studies have stated that selenium both has a negative influence on the absorption of nitrate and causes the inhibition of the NR enzyme; however, in species such as wheat, there is evidence of an increase in NR activity when selenium is applied in the form of selenite (Nowak et al., 2004). Under our experimental conditions, the foliar application of Se did not affect the accumulation of nitrate in chard.

Regarding the Fe foliar applications, four foliar spray applications resulted in a statistically significant effect on the accumulation of nitrate at doses of $5000 \mathrm{mg} \mathrm{L}^{-1}$ (Figure 5A). In addition, there was only a significant 
effect of the Fe $\mathrm{x}$ Se interaction on the accumulation of shoot nitrate after four applications. For the 5000 $\mathrm{mg} \mathrm{L}^{-1}$ concentration of $\mathrm{Fe}$, a greater accumulation of nitrate in leaf tissue was recorded (Figure 5B), which indicates that high doses of $\mathrm{Fe}$ inhibit the functioning of enzymes such as NR and nitrite reductase (NiR) and can cause a significant increase in nitrate accumulation.

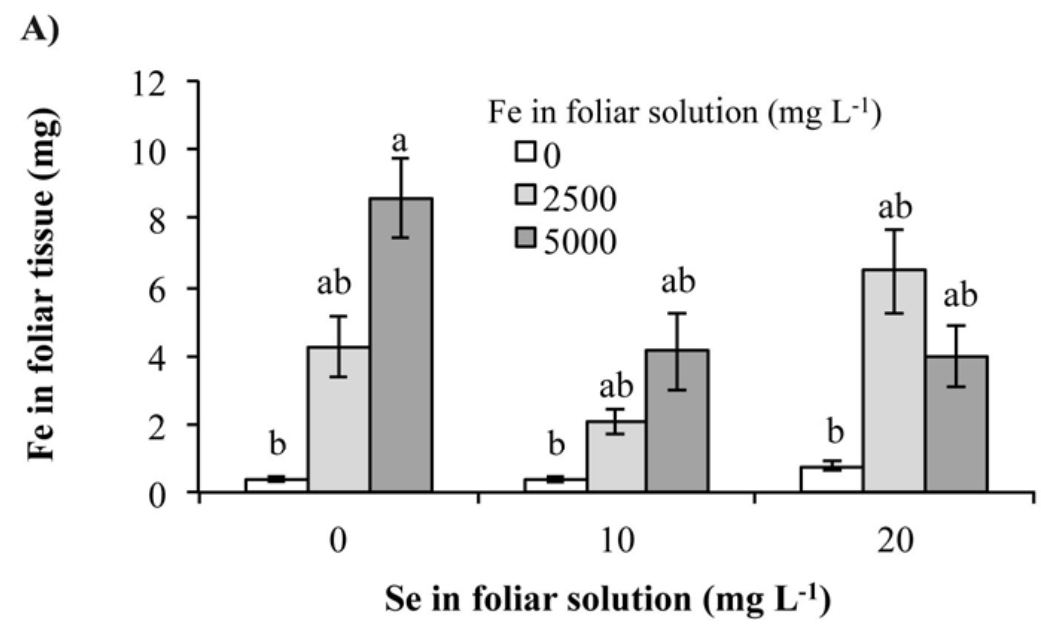

B)

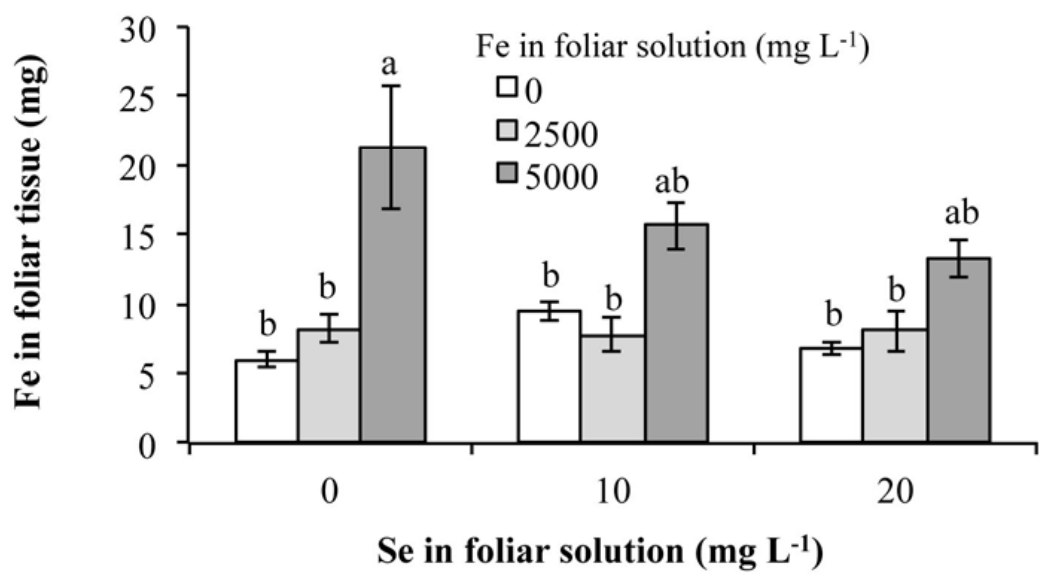

Figure 4. Effect of the Fe $\mathrm{x}$ Se interaction on the accumulation of Fe in the aerial portion of chard plants after two (A) and four (B) foliar spray applications at intervals of $15 \mathrm{~d}$. Means \pm SD with different letters in each subfigure indicate significant differences (Tukey, 0.05). 


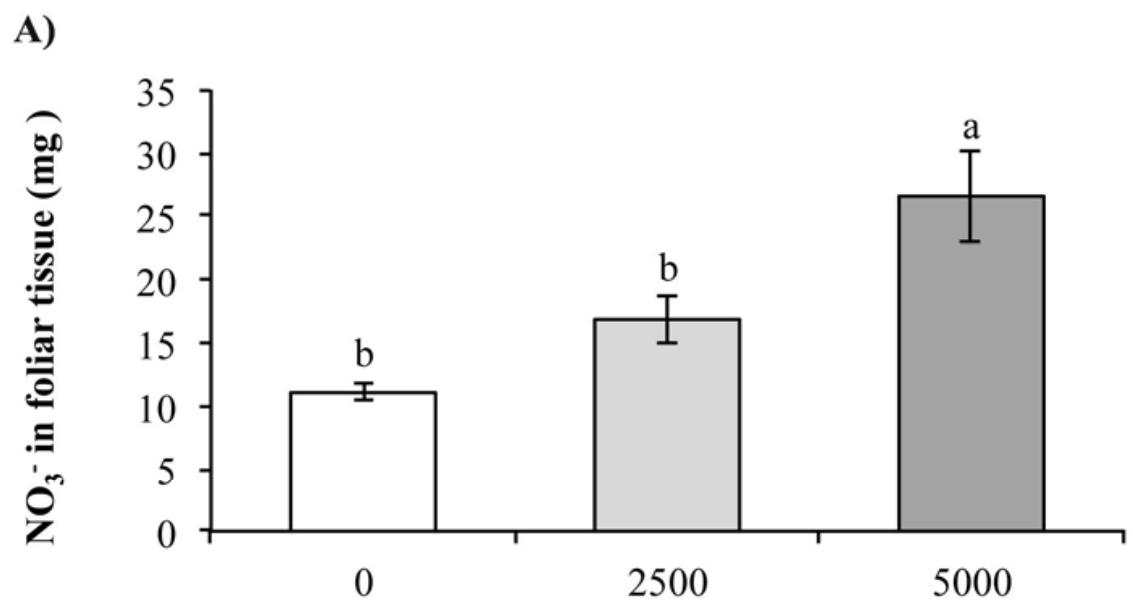

Fe in foliar solution $\left(\mathrm{mg} \mathrm{L}^{-1}\right)$

B)

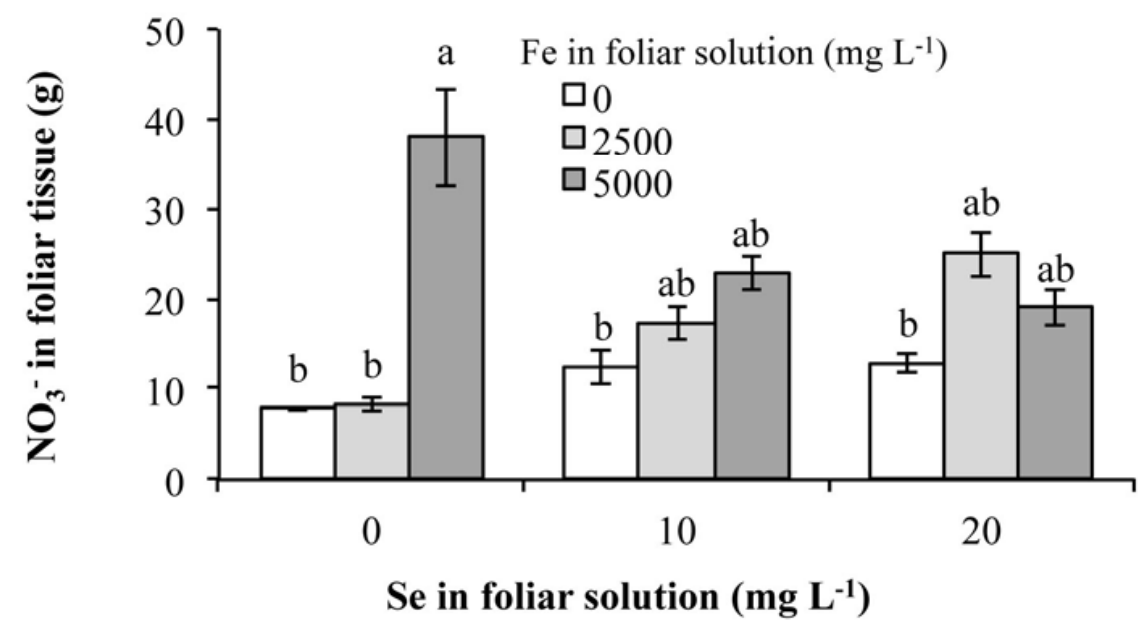

Figure 5. Principal effect of $\mathrm{Fe}(\mathrm{A})$ and the interaction of $\mathrm{Se} x \mathrm{Fe}$ on the accumulation of nitrate in the aerial portion of chard plants after four foliar spray applications at intervals of $15 \mathrm{~d}$. Means \pm SD with different letters indicate significant differences (Tukey, 0.05).

\subsection{Accumulation of proteins in the shoot}

The accumulation of proteins in the shoot was significantly affected by the principal effects of both
$\mathrm{Fe}$ and $\mathrm{Se}$ and their interaction $\left(\mathrm{Se}{ }^{\mathrm{x}} \mathrm{Fe}\right)$ at both sampling dates.

As observed in Figure 6A, the accumulation of protein is evident after two spray applications of 20 
$\mathrm{mg} \mathrm{L} \mathrm{L}^{-1}$ of Se. The highest accumulation of proteins was observed after four foliar spray applications of 20 $\mathrm{mg} \mathrm{L}^{-1}$ of Se, although this accumulation of Se is not significantly different from what was recorded when $10 \mathrm{mg} \mathrm{L}^{-1}$ was applied (Figure 6B).

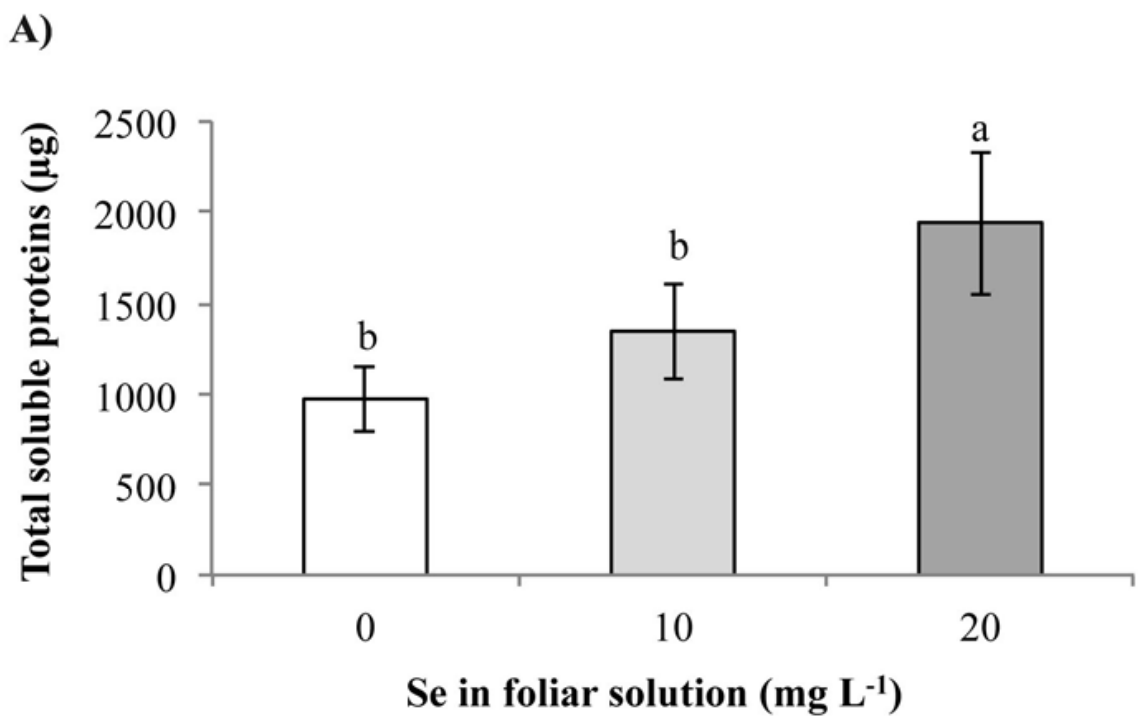

B)

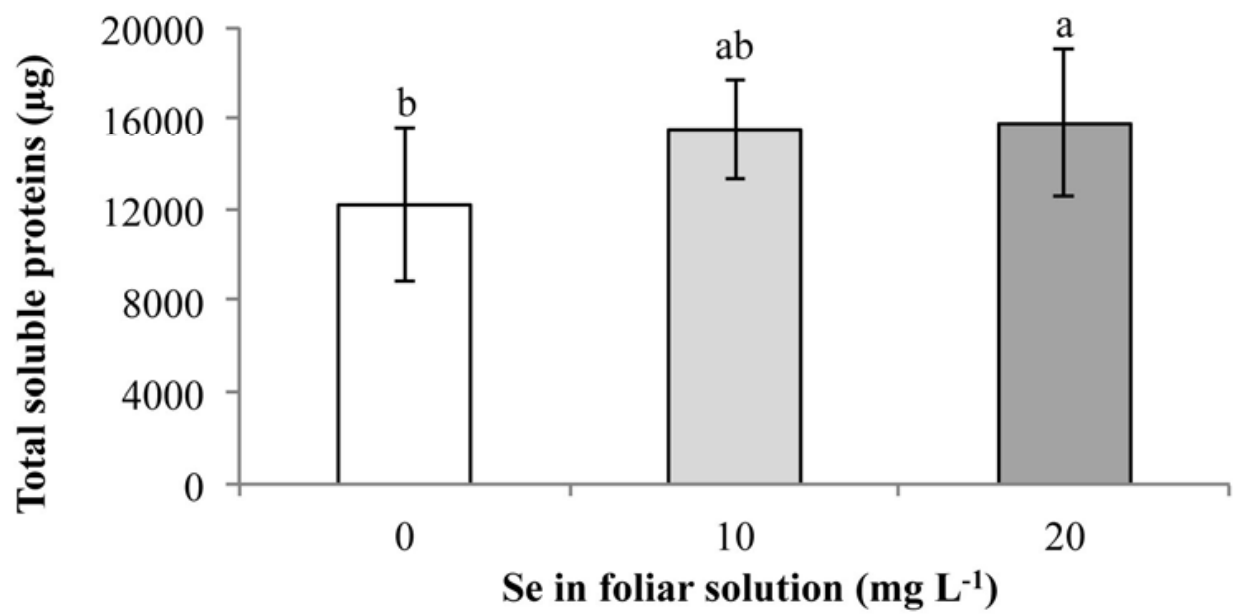

Figure 6. Principal effect of Se on the accumulation of proteins in the aerial portion of chard plants treated with two (A) and four (B) foliar spray applications at intervals of $15 \mathrm{~d}$. Means \pm SD with different letters in each subfigure indicate significant differences (Tukey, 0.05). 


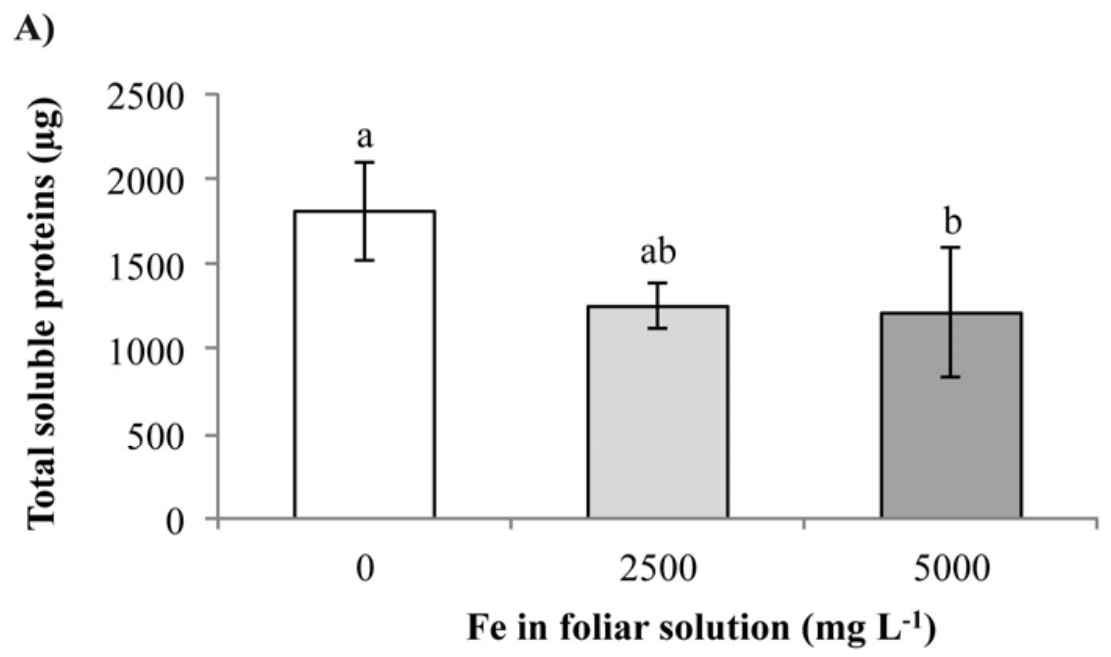

B)

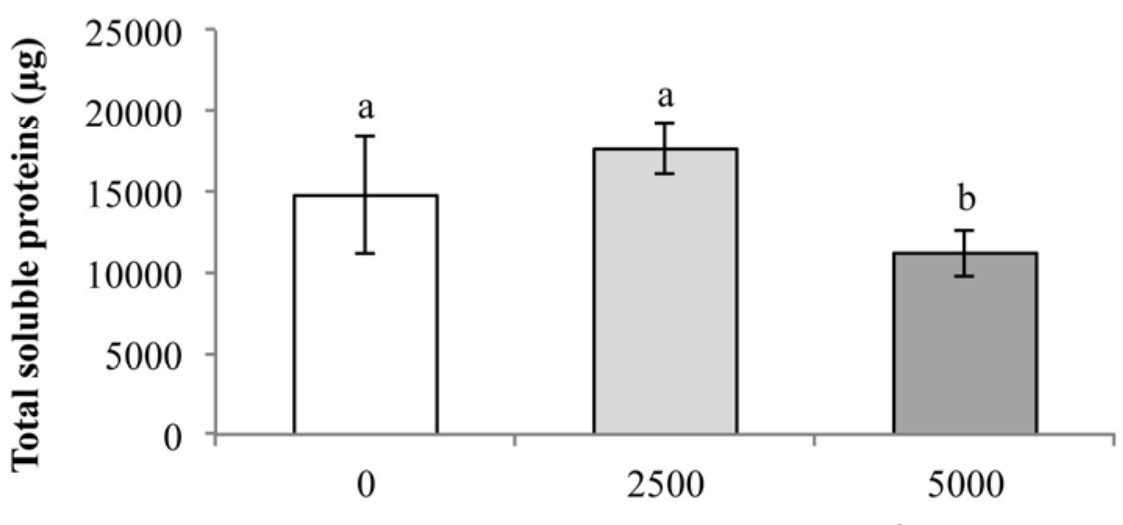

$\mathrm{Fe}$ in foliar solution $\left(\mathrm{mg} \mathrm{L}^{-1}\right)$

Figure 7. Principal effect of Fe on the accumulation of proteins in the aerial portion of chard plants treated with two (A) and four (B) foliar spray applications at intervals of $15 \mathrm{~d}$. Means \pm SD with different letters in each subfigure indicate significant differences (Tukey, 0.05).

In this study, a greater accumulation of proteins was related to a greater accumulation of Se in the aerial portion of chard, confirming that Se is an element with potential for increasing the accumulation of total soluble proteins in plant tissues when applied to leaves, at certain concentrations and times. These results are consistent with those reported for canola (Brassica napus) and turnip (Brassica rapa); the application of Se to the foliage or roots of these species improves their nutritional quality by increasing the protein fraction and the amount of Se-methionine (Seppänen et al., 2010). 
Similarly, applications of selenite $\left(\mathrm{SeO}_{3}^{2-}\right)$ have been reported to increase the protein content in potato tubers (Solanum tuberosum L.) and reduce the content of free amino acids. The majority of the Se in tubers was contained within the protein fraction (49-65\%), and the concentration of Se was lowest in the leaves in another study (Turakainen et al., 2004).

When selenium is supplied as selenate, it is transformed into organic Se in the plant, to be incorporated into biomolecules, following the metabolic pathway of sulfur (S) in chloroplasts, from which cysteine is the final product for the assimilation of the $\mathrm{S}$ for the subsequent formation of methionine and its incorporation into proteins or other organosulfur compounds (White et al., 2004). Similarly, the final destination for Se, following the assimilation route of $\mathrm{S}$, is the formation of Se-cysteine that is later incorporated into Se-methionine and finally incorporated into proteins.

Selenium can also induce the synthesis and accumulation of cysteine that is used for the formation of non-protein organosulfur compounds, which include vitamins, cofactors, and important antioxidant biomolecules such as glutathione. Glutathione plays an important role in cell defense and protection and protects proteins against denaturation caused by stress (Noctor et al., 2002).

After two foliar spray applications of $\mathrm{Fe}$, a negative effect of this element on the accumulation of shoot proteins was observed at high doses (Figure 7A). After four foliar spray applications, the greatest accumulations of shoot proteins were recorded with doses of Fe less than or equal to $2500 \mathrm{mg} \mathrm{L}^{-1}$, resulting in a negative effect of the highest Fe concentration on protein accumulation (Figure 7B).

However, the protein accumulation results obtained in this research differ from those reported by Jin et al. (2008), who reported that foliar applications of the Fe complex of $1000 \mathrm{mg} \mathrm{L}^{-1} \mathrm{FeSO}_{4}$ and $4000 \mathrm{mg} \mathrm{L}^{-1}$ amino acids increased protein and amino acid concentrations by $30.9 \%$ and by $37.0 \%$, respectively, in rice.

It is important to note that after two and four foliar spray applications, the lowest accumulation of leaf proteins (Figure 8) coincides with the highest dose of $\mathrm{Fe}$ sprayed foliarly and therefore with the greatest accumulations in the shoot (Figures 4A and 4B). In addition, after four foliar spray applications, the lowest protein accumulation (Figure $8 \mathrm{~B}$ ) also coincided with the greatest accumulation of nitrate (Figure 5B).

In the present study, foliar applications of $5000 \mathrm{mg}$ $\mathrm{L}^{-1}$ of Fe significantly affected the accumulation of proteins in chard plants. Although doses of $5000 \mathrm{mg}$ $\mathrm{L}^{-1}$ significantly increased the accumulation of $\mathrm{Fe}$ in leaf tissue after two and four foliar spray applications, they also caused a greater accumulation of nitrate and consequently a negative effect on protein formation because while the concentration of total $\mathrm{Fe}$ in leaves is high, it is possible that only a portion of this $\mathrm{Fe}$ enters the metabolism of the plant (Mohamadipoor et al., 2013). In addition, high levels of free $\mathrm{Fe}^{2+}$ are responsible for the generation of oxygen radicals that form hydroxyl radicals, which are extremely harmful to the vast majority of biologically important molecules, including proteins.

The decrease in the enzymatic activity of NR and $\mathrm{NiR}$ adversely affects nitrogen metabolism because a decrease in $\mathrm{NO}_{3}{ }^{-}$reduction implies a decrease in the activity of enzymes of the GS/GOGAT cycle and therefore a decrease in the quantity of final products, such as amino acids and proteins, which also reduces plant growth (Nowak et al., 2004).

Regarding the Fe $\mathrm{x}$ Se interaction after two foliar spray applications (Figure 8A), there was a marked decrease in the accumulation of proteins without the addition of $\mathrm{Se}$ as the Fe concentration increased. In the absence of Se and after four foliar spray applications, the dose of $2500 \mathrm{mg} \mathrm{L}^{-1}$ of Fe caused a greater protein accumulation (Figure 8B). 


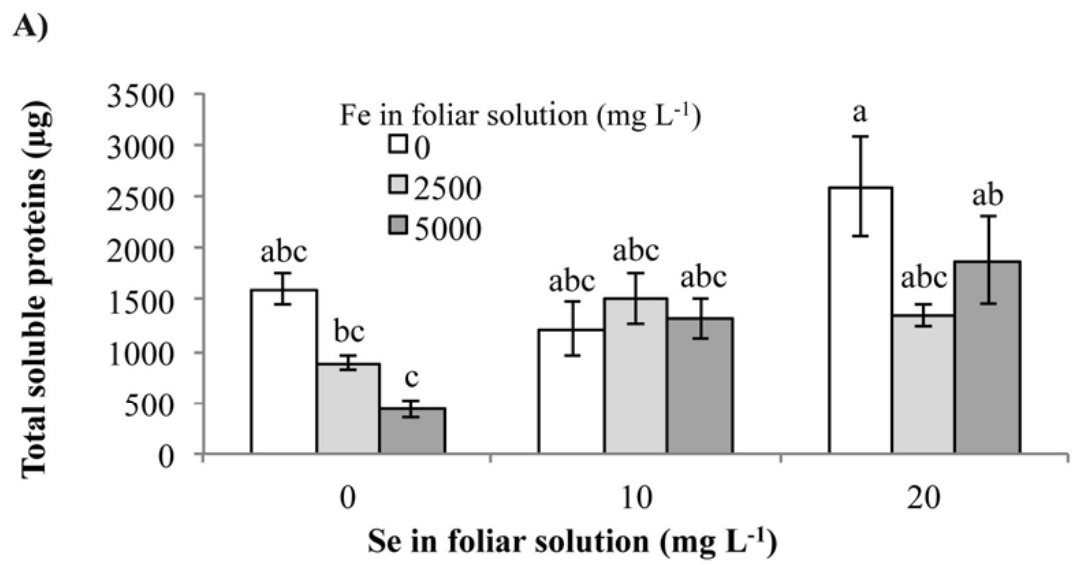

B)

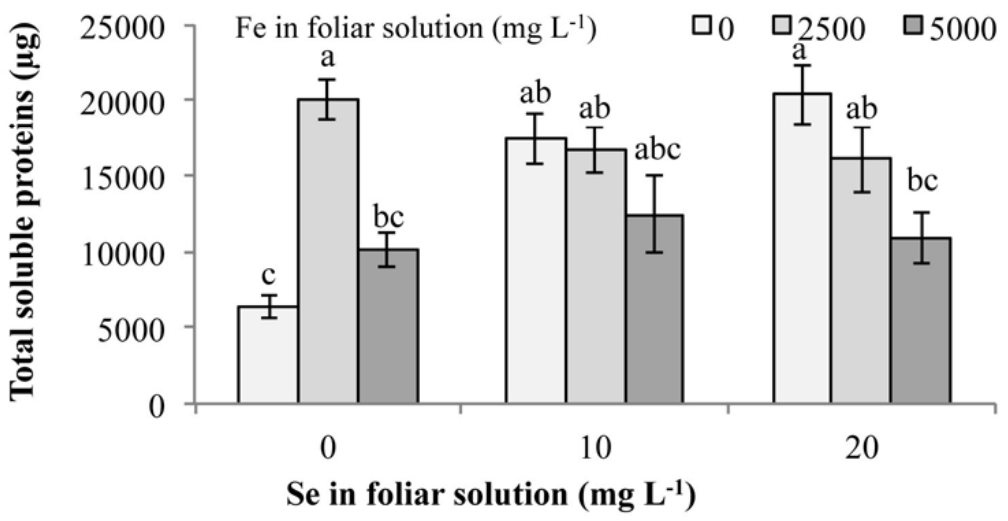

Figure 8. Effect of the interaction of Se $x$ Fe on the accumulation of proteins in the aerial portion of chard plants treated with two (A) and four (B) foliar spray applications at intervals of $15 \mathrm{~d}$. Means \pm SD with different letters in each subfigure indicate significant differences (Tukey, 0.05).

Though the main roles of essential elements have been well documented, many aspects related to whole-plant nutrition await for further investigation. Just recently, Pinto and Ferreira (2015) reported that cation transporters/channels are key players in a wide range of physiological functions in plants, while the molecular mechanisms responsible for these processes that can be used to increase nutrient phytoavailability and nutrients accumulation in the edible tissues of plants require further studies. This is especially important for elucidating the main metabolic roles of trace elements such as $\mathrm{Fe}$ and $\mathrm{Se}$ in biofortification.

\section{Conclusions}

Increasing application concentrations of $\mathrm{Se}$ and $\mathrm{Fe}$ promoted a greater accumulation of these elements in foliar tissue. The greatest accumulations of proteins 
occurred after two and four foliar applications of Se at a dose of $20 \mathrm{mg} \mathrm{L}^{-1}$. Under our experimental conditions, the foliar application of Se did not affect the accumulation of nitrate in chard. A foliar application dose of $5000 \mathrm{mg} \mathrm{L}^{-1}$ of $\mathrm{Fe}$ caused a decrease in protein accumulation after two and four foliar applications. Only after four foliar applications of $\mathrm{Fe}$ at a dose of $5000 \mathrm{mg} \mathrm{L}^{-1}$ was there an increase in nitrate accumulation in leaf tissues. According to the results, the biofortification of chard with $\mathrm{Fe}$ and $\mathrm{Se}$ is possible when foliarly supplied.

\section{Acknowledgements}

We thank the Priority Line of Research No. 5 on Microbial, Plant and Animal Biotechnology and the Colegio de Postgraduados for the support provided for this research. We also thank the National Science and Technology Council (CONACYT) of Mexico for the scholarship given to EHC for doctoral studies.

\section{References}

Alcántar, G.G., Sandoval, V.M. 1999. Manual de análisis químico de tejido vegetal. Guía de muestreo, preparación, análisis e interpretación. Publicación Especial No. 10 de la Sociedad Mexicana de la Ciencia del Suelo A. C., Chapingo, México. 156 p.

Broadley, M.R., White, P.J., Bryson, R.J., Meacham, M.C., Bowen, H.C., Johnson, S.E., Hawkesford, M.J., McGrath, S.P., Zhao, F.J., Breward, N., Harriman, M., Tucker, M. 2006. Biofortification of UK food crops with selenium. P. Nutr. Soc. 65(2), 169-181.

Campbell, W.H. 2001. Structure and function of eukaryotic NAD(P)H:nitrate reductase. Cell. Mol. Life Sci. 58, 194-204.
Cartes, P., Gianfreda, L., Paredes, C., Mora, M.L. 2011. Selenium uptake and its antioxidant role in raygrass cultivars as affected by selenite seed pelletization. J. Soil Sci. Plant. Nutr. 11, 1-14.

DRI. 2000. Dietary reference intakes for selenium. In: Dietary references intakes for vitamin C, vitamin E, selenium and carotenoids. National Research Council. National Academy Press. Washington, DC. USA. pp: 284-319.

Ducsay, L., Lozek, O. 2006. Effect of selenium foliar application on its content in winter wheat grain. Plant, Soil Environ. 52(2), 78-82.

Duffield, L. A. J., Reid, M. E., Turnbull, B. W., Combs, G. F., Slate, E. H., Fischbach, L. A., Marshall, J. R., Clark, L. C. 2002. Baseline characteristics and the effect of selenium supplementation on cancer incidence in a randomized clinical trial: A summary report of the Nutritional Prevention of Cancer Trial. Cancer Epidem. Biomar. 11, 630639.

FAO. 2011. Combating micronutrient deficiencies. Food-based approaches. Organization of the United Nations for Food and Agriculture. Rome, Italy, 397 p. http://www.fao.org/docrep/013/ am027e/am027e.pdf

Hord, N.G., Ghannam, J.S., Garg, H.K., Berens, P.D., Bryan, N.S. 2011. Nitrate and nitrite content of human, formula, bovine, and soy milks: Implications for dietary nitrite and nitrate recommendations. Breastfeed. Med. 6(6), 393399.

Ježek, P., Škarpa, P., Lošák, T., Hlušek, J., Jůzl, M., Elzner, P. 2012. Selenium - An important antioxidant in crops biofortification. In: M. A. El-Missiry (ed.). Antioxidant enzyme, InTech. Croatia. pp: 343-368. 
Jin, Z., Minyan, W., Lianghuan, W., Jiangguo, W., Chunhai, S. 2008. Impacts of combination of foliar iron and boron application on iron biofortification and nutritional quality of rice grain. J. Plant Nutr. 31(9), 1559-1611.

Kopsell, D.A., Randle, W.M., Mills, H.A. 2000. Nutrient accumulation in leaf tissue of rapidcycling Brassica oleracea responds to increasing sodium selenate concentrations. J. Plant Nutr. 23, 927-935.

Kopsell, D.A, Sams, C.E., Barickman, T.C., Deyton, D.E. 2009. Selenization of basil and cilantro through foliar applications of selenate-selenium and selenite-selenium. HortScience. 44(2), 438442.

Kopsell, D.A., Sams, C.E., Charron, C.S., Randle, W.M., Kopsell, D.E. 2007. Kale carotenoids remain stable while glucosinolates and flavor compounds respond to changes in selenium and sulfur fertility. Acta Hortic. 744, 303-309.

Lefsrud, M.G., Kopsell, D.A., Kopsell, D.E., Randle, W.M. 2006. Kale carotenoids are unaffected by, whereas Biomass production, Elemental concentrations, and selenium accumulation to, changes in selenium fertility. J. Agric. Food Chem. 54, 1764-1771.

Manion, L.K., Kopsell, D.E., Kopsell, D.A., Sams, C.E., Rhykerd, R.L. 2013. Selenium Fertilization Influences Biomass, Elemental Accumulations, and Phytochemical Concentrations in Watercress. J. Plant Nutr. 37(2), 327-342.

Mao, H., Wang, J., Zan, Y., Lyons, G., Zou, C. 2014. Using agronomic biofortification to boost zinc, selenium, and iodine concentrations of food crops grown on the loess plateau in China. J. Soil Sci. Plant Nutr. 14(2), 459-470.
Mohamadipoor, R., Sedaghathoor, S., Khomami, A.M. 2013. Effect of application of iron fertilizers in two methods 'foliar and soil application' on growth characteristics of Spathyphyllum illusion. Eur. J. Exp. Biol. 3, 232-240.

Noctor, G., Gómez, L., Vanacker, H., Foyer, C.H. 2002. Interactions between biosynthesis, compartmentation and transport in the control of glutathione homeostasis and signalling. J. Exp. Bot. 53, 1283-1304.

Nowak, J., Kakiewski, K., Ligocki, M. 2004. Influence of selenium on oxidoreductive enzymes activity in soil and in plants. Soil Biol. Biochem. 36(10), 1553-1558.

Pinto, E., Ferreira, I.M. 2015. Cation transporters/ channels in plants: Tools for nutrient biofortification. J. Plant Physiol. 79, 64-82. doi: 10.1016/j.jplph.2015.02.010.

Rayman, M.P. 2004. The use of high-selenium yeast to raise selenium status: how does it measure up? Brit. J. Nutr. 92, 557-573.

Rayman, M.P. 2008. Food-Chain selenium and human health: emphasis on intake. Brit. J. Nutr. 100, 254268.

Rehman, A., Farooq, M., Cheema, Z.A., Nawaz, A., Wahid, A. 2014. Foliage applied boron improves the panicle fertility, yield and biofortification of fine grain rice. J. Soil Sci. Plant Nutr. 14, 723-733.

Seppänen, M.M., Kontturi, J., Lopez, H.I., Madrid, Y., Cámara, C., Hartikainen, H. 2010. Agronomic biofortification of Brassica with selenium: enrichment of SeMet and its identification in Brassica seeds and meal. Plant Soil. 337, 273-283.

Thompson, B. 2007. Food-based approaches for combating iron deficiency. Nutritional anemia. Roma, Italia. 337 p. 
Turakainen, M., Hartikainen, H., Seppänen, M. 2004. Effect of selenium treatments on potato (Solanum tuberosum L.) growth and concentration of soluble sugars and starch. J. Agric. Food Chem. $52,5378-5382$.

Wei, Y., Shohag, M.J.I., Yang, X., Yibin, Z. 2012. Effects of foliar iron application on iron concentration in Polished rice grain and its bioavailability. J. Agric. Food Chem. 60(45), 11433-11439.
White, P.J., Bowen, H.C., Parmaguru, P., Fritz, M., Spracklen, W.P., Spiby, R.E., Meacham, M.C., Mead, A., Harriman, M., Trueman, L.J., Smith, B.M., Thomas, B., Broadley, M.R. 2004. Interactions between selenium and sulfur nutrition in Arabidopsis thaliana. J. Exp. Bot. 55, 1927-1937.

Wu, Z., Bañuelos, G.S., Lin, Z.Q., Liu, Y., Yuan, L., Yin, X. Li, M. 2015. Biofortification and phytoremediation of selenium in China. Front. Plant Sci. 6, 136. doi: 10.3389/fpls.2015.00136. 